\title{
EDUCAÇÃO E RELIGIÃO: O NOVO MODELO DE ENSINO \\ RELIGIOSO NAS ESCOLAS PÚBLICAS DO ESTADO DO RIO \\ GRANDE DO SUL
}

\author{
Cesar A. Ranquetat Júnior ${ }^{1}$
}

\begin{abstract}
Resumo: O presente texto procura examinar, o processo de implementação do novo modelo de ensino religioso nas escolas públicas do estado do Rio Grande do Sul, em obediência à Lei Federal 9.475/97. Demonstra o predomínio de igrejas cristãs, principalmente a Igreja Católica na organização e administração do ensino religioso e a persistência, no Rio Grande do Sul, de práticas confessionais e proselitistas contrastantes com a proposta legal de uma disciplina de ensino religioso não-confessional e pluralista.
\end{abstract}

Palavras-chave: Ensino Religioso, pluralismo, Igreja Católica, escolas públicas.

\begin{abstract}
This article analyses the implementation process of the new religious education model in public schools in Rio Grande do Sul, according to the 9.475/97 Federal Law. It brings out the predominance of Christian churches, mainly the Catholic Church, in the organization and administration of religious education, the persistence, in Rio Grande do Sul, of confessional practices and proselytism contrasting with the legal proposal of a non-confessional and pluralist religious education.
\end{abstract}

Keywords: Religious education, pluralism, Catholic Church, public schools.

\section{INTRODUÇÃO}

Neste artigo analisa-se a implantação do novo modelo de ensino religioso nas escolas públicas do estado do Rio Grande do Sul. Denomino novo ensino religioso, pois, com o artigo 33 da LDB de 1996 modificado pela Lei Federal 9.475/97, o ensino religioso nas escolas públicas é proposto como uma disciplina que objetiva à formação básica do cidadão e que deve respeitar a diversidade religiosa da sociedade brasileira, proibindo qualquer forma de doutrinação ou proselitismo. Conforme a nova lei cabe aos sistemas de ensino a definição dos conteúdos da disciplina e a habilitação dos professores. Tradicionalmente, o ensino religioso nas escolas públicas brasileiras era

1 Mestre em Ciências Sociais pela PUC-RS e Doutorando em Antropologia Social pela UFRGS. Bolsista Capes. Email: franquetat@yahoo.com.br 
organizado pelas denominações religiosas, que definiam os conteúdos e escolhiam os professores que ministravam as aulas. Diante deste quadro o Estado apenas cedia o espaço das escolas públicas para que a disciplina fosse ministrada. Todavia, com a Lei Federal 9.475/97, o Estado delega as escolas e a uma entidade civil composta por múltiplas denominações religiosas, conhecida como CONER (Conselho do Ensino Religioso), tais funções. Esse novo enfoque do ensino religioso é antropológicocultural, visando estudar o fenômeno religioso, concebido como algo inerente ao homem e presente em todas as sociedades.

Vale ressaltar que o estado do Rio Grande do Sul, ao contrário de outros estados, até o momento não aprovou qualquer lei estadual referente a tal questão. De modo que o processo de regulamentação dessa disciplina, em sua nova modalidade, está ocorrendo por meio de pareceres e resoluções emitidas pelo Conselho Estadual de Educação. Contudo, a Constituição Estadual do Rio Grande do Sul, de 1989, no artigo 209, parágrafo $1^{\circ}$, estabelece que "o ensino religioso, de matrícula facultativa, constituirá disciplina dos horários normais das escolas públicas do ensino fundamental e médio".

Destaca-se, que a Constituição gaúcha apresenta uma particularidade no que tange ao ensino religioso nas escolas públicas, pois determina que essa disciplina deva ser ministrada também nas escolas públicas de ensino médio. A matéria em questão foi objeto de discussões ao longo da Assembléia Constituinte gaúcha de 1989. Foram apresentadas diversas emendas ao projeto inicial, que imitava o artigo 210 , parágrafo $1^{\circ}$, da Constituição Federal de 1988. A modificação que estende o ensino religioso às escolas públicas de ensino médio na Constituição Rio-Grandense se deve à emenda $\mathrm{n}^{\circ}$. 0046, de 18/09/1989, de autoria da CNBB (Conferência Nacional dos Bispos do Brasil). A emenda adita ao parágrafo $1^{\circ}$, do então artigo 261 , a expressão "ensino médio".

O modelo de ensino religioso adotado nas escolas públicas do estado do Rio Grande do Sul segue, grosso modo, as orientações da Lei Federal, sendo supraconfessional e inter-religioso, vedando qualquer forma de doutrinação e proselitismo, buscando respeitar a diversidade religiosa da sociedade gaúcha. Entretanto, como se pôde constatar na pesquisa de campo, o ensino religioso nas escolas públicas gaúchas ainda possui, em parte, um teor confessional cristão e, muitas vezes, proselitista, o que contrasta com o ideal pluralista e inter-religioso defendido pelos principais atores envolvidos na implantação dessa disciplina. 


\section{A COORDENAÇÃO DO ENSINO RELIGIOSO DA SECRETARIA DE EDUCAÇÃO DO ESTADO}

Com o objetivo de esclarecer os agentes envolvidos no processo educacional sobre a nova modalidade de ensino religioso, a Secretaria de Educação do Estado do Rio Grande do Sul, por meio da Coordenação do Ensino Religioso, dirigida desde janeiro de 2004 pela irmã Vilma Rech, está realizando um trabalho de conscientização sobre a nova proposta. O Rio Grande do Sul é hoje um dos únicos estados brasileiros que possui uma coordenadoria própria, específica para o ensino religioso. A Coordenação do Ensino Religioso constitui um dos principais atores no processo de implantação dessa disciplina em sua nova modalidade.

Essa Coordenação existe desde 1972, quando foi elaborado um plano de reestruturação da educação religiosa por um conjunto de igrejas: Igreja Católica Apostólica Romana, Igreja Evangélica de Confissão Luterana no Brasil, Igreja Metodista e Igreja Episcopal do Brasil. O plano previa ainda a criação de uma equipe interconfessional, que foi criada em 21 de junho de 1972. O primeiro coordenador geral do ensino religioso no Rio Grande do Sul foi o irmão lassalista Carlos Mombach, que ficou na coordenação de 1972 até 1980. Foi sucedido pela irmã franciscana Helena Perini, que permaneceu na função de 1980 a 1988. Em 1988 assume a coordenação o frei capuchinho Oscar Andrade Santos, que exerceu o cargo até 2002. É a partir do início da década de 70 que o ensino religioso no Rio Grande do Sul começa a apresentar um teor ecumênico, interconfessional cristão. A Coordenação do Ensino Religioso, criada nesse período, visava em conjunto com a equipe interconfessional, implantar essa modalidade ecumênica de ensino. O plano de reestruturação do ensino religioso seguia o espírito da LDB 5.692, de 1971, que reformulou muitos aspectos do ensino no país. Essa tendência ao ecumenismo e à interconfessionalidade no ensino religioso também se deu em outros estados, como Santa Catarina, e refletia as novas idéias advindas do Concílio Vaticano II e da Conferência Geral do Episcopado Latino-Americano, realizada em Medellín (Figueiredo, 1996).

Todos os coordenadores do ensino religioso, na Secretaria de Educação do Rio Grande do Sul, eram ligados à Igreja Católica. De modo que o plano de reestruturação do ensino religioso do começo da década de 70 foi impulsionado, em grande parte pelos católicos. Neste sentido, o processo de reestruturação do ensino religioso, levado a cabo no início da década de 70, guarda semelhanças com a implantação do novo modelo de ensino religioso, originado a partir da Lei 9.475/97. A equipe interconfessional foi 
sucedida pelo CONER-RS ${ }^{2}$ e a coordenação do ensino religioso foi revitalizada com o objetivo de implantar o "novo ensino religioso". O coordenador do ensino religioso continua sendo uma pessoa vinculada à Igreja Católica, e o CONER-RS apresenta mais a característica de um grupo ecumênico, interconfessional cristão, do que propriamente uma organização inter-religiosa. Conforme Giumbelli (2004, p.53) "historicamente, o ensino religioso esteve ligado aos interesses e à influência da Igreja Católica na sociedade brasileira. Outras tradições religiosas, quando não se opuseram, não se envolveram na questão".

A primeira tarefa dessa coordenação foi esclarecer as escolas públicas do estado que o ensino religioso é uma área de conhecimento, uma disciplina curricular prevista na Constituição Federal e Estadual e na Lei Federal 9.475./97. A Coordenação do Ensino Religioso solicitou que em cada $\mathrm{CRE}^{3}$ (Coordenadoria Regional de Educação) houvesse um coordenador do ensino religioso. O coordenador do ensino religioso em cada CRE desenvolve um trabalho de supervisão e orientação, verificando a presença dessa disciplina nas escolas, reunindo-se com os professores, articulando-se com outras entidades para informar todos os envolvidos com a educação sobre a nova modalidade de ensino religioso.

No segundo semestre de 2004, foi publicado pela Secretaria de Educação do estado do Rio Grande do Sul o documento "O Ensino Religioso no Sistema Estadual de Ensino do Rio Grande do Sul - orientações técnicas para a oferta do ensino religioso." O documento foi enviado a todas as escolas do sistema estadual de ensino com a finalidade de orientar a direção das escolas, professores e outros atores sociais envolvidos com o ensino religioso sobre a nova proposta da disciplina. Reproduz-se aqui um trecho do documento em sua apresentação:

Partindo-se de uma perspectiva holística do processo educacional desenvolvido nos Estabelecimentos Estaduais de Ensino Público, tem se priorizado a formação integral do cidadão, destacando-se a religiosidade num contexto multicultural, respeitando-se a diversidade de suas manifestações. Desta forma, o Ensino Religioso, Área de Conhecimento reconhecida pela Resolução CEB/CNE 02/98, tem sido

\footnotetext{
2 CONER-RS (Conselho do Ensino Religioso do Rio Grande do Sul), entidade civil criada em 1997 que congrega diversas denominações religiosas e que de acordo com a Lei 9.475/97, deve ser ouvida pelo sistema de ensino na definição dos conteúdos da disciplina de ensino religioso.

3 Cada coordenadoria regional de educação reúne um conjunto de municípios de determinada região. No Rio Grande do Sul há trinta coordenadorias regionais de educação, em cada uma delas há um coordenador de ensino religioso que trabalha em parceria com as denominações religiosas e com a entidade civil prevista em lei, para formar e capacitar professores, conscientizando a direção das escolas públicas sobre a nova proposta
} 
priorizado pela Secretaria de Educação, no sentido de oferecer às comunidades escolares gaúchas uma educação integral, integrante e integrado em nossa sociedade.

No documento, percebe-se a preocupação da Secretaria de Educação do Estado em demonstrar que a religiosidade e a educação da religiosidade se inserem no esforço de educar o homem em sua integralidade e que essa educação deve respeitar a diversidade cultural e religiosa da sociedade brasileira. A Coordenação do Ensino Religioso tem procurado adotar um discurso pluralista e inter-religioso, de acordo com a nova lei.

Contudo o trabalho desenvolvido pela Coordenação do Ensino Religioso tem esbarrado em muitas dificuldades, na medida em que grande parte dos professores das escolas públicas e dos alunos continua pensando e "praticando" a modalidade confessional de ensino religioso de caráter cristocêntrico. De acordo com a Irmã Vilma Rech:

Fazemos um trabalho de conscientização com as denominações. Demonstramos que o ensino religioso não é mais religião, é conhecimento. Então muitas denominações estão perdendo o interesse, pois queriam fazer uma catequese, proselitismo religioso. Algumas denominações têm dificuldade de entender essa nova proposta, isso é um pouco complicado.

$\mathrm{Na}$ discussão sobre a definição e conceituação do ensino religioso, a Coordenação acabou por adotar uma concepção valorativa e não proselitista do ensino religioso (Dickie, 2007). O valor central que se busca transmitir é Deus, o transcendente, sem fazer referência a uma tradição religiosa em particular.

A Coordenação do Ensino Religioso e a diretoria do CONER-RS, liderada pelo Padre Enrique Ilarze, insistem em afirmar que o ensino religioso tem como objetivo educar a dimensão religiosa do ser humano, e não fazer proselitismo desta ou daquela confissão religiosa. Neste sentido, observa-se que os integrantes do CONER-RS e da Coordenação do Ensino Religioso assumem um discurso "macro-ecumênico" e de defesa do religioso, como um aspecto fundamental do homem e da cultura. Evitam fazer menções a suas confissões religiosas, em nenhum momento se referem a Cristo, aos Evangelhos e a outros elementos da tradição cristã. 


\section{O CONER-RS}

A Lei Federal $\mathrm{n}^{\circ}$. 9475/97 afirma, em seu parágrafo $2^{\circ}$, a necessidade de ser ouvida entidade civil, formada por diferentes denominações religiosas, para a definição dos conteúdos do ensino religioso. A partir dessa definição legal, foram constituídos, em diversos estados brasileiros, conselhos de ensino religioso, os chamados CONER (Conselho do Ensino Religioso), compostos por várias denominações religiosas. No estado do Rio Grande do Sul foi fundado, em 26 de novembro de 1997, o CONER-RS (Conselho do Ensino Religioso do estado do Rio Grande do Sul), quatro meses após a Lei 9.475/97. O CONER-RS é um sucedâneo do GTERI (Grupo Tarefa para o Ensino Religioso Interconfessional) ${ }^{4}$, criado em 1990, que tinha como objetivo elaborar uma proposta de ensino religioso interconfessional cristão.

O CONER-RS atual é composto pelas mesmas denominações religiosas que faziam parte do Grupo Interconfessional, incluindo a Confissão Israelita. Há um predomínio cristão na composição do CONER-RS, a única denominação não-cristã, a Israelita, tem vínculos históricos com as denominações cristãs. O predomínio de denominações cristãs na formação do CONER-RS não é casual e está relacionado com as dificuldades que o primeiro estatuto do CONER-RS definia para que denominações religiosas fizessem parte dessa entidade civil. O critério para fazer parte do CONERRS, era que a organização religiosa tivesse vinte anos de existência e presença em pelo menos dez municípios do estado. O estatuto do CONER-RS foi modificado para permitir que qualquer denominação religiosa fizesse parte dessa organização, desde que fosse registrada em cartório como pessoa jurídica em qualquer comarca do estado do Rio Grande do Sul.

Como já foi demonstrado, o CONER-RS é um sucessor do grupo de trabalho interconfessional criado no começo da década de 90, que era um substituto da antiga Equipe Interconfessional criada no início da década de 70. Eram compostos por denominações cristãs que defendiam um ensino religioso ecumênico de orientação cristã nas escolas públicas. De acordo com um influente membro do CONER-RS ${ }^{5}$ atual, essa herança continua presente, na medida em que algumas lideranças das

\footnotetext{
4 O GTERI (Grupo Tarefa para o Ensino Religioso Interconfessional) era composto pelas seguintes denominações religiosas: Convenção Batista do Rio Grande do Sul, Igreja Católica Apostólica Romana, Igreja Episcopal Anglicana do Brasil, Igreja Evangélica de Confissão Luterana do Brasil, Igreja Evangélica Luterana do Brasil e Igreja Metodista do Brasil. Esse grupo elaborou uma proposta de ensino religioso interconfessional e de caráter eminentemente cristão em março de 1996. No estudo e na votação final, aprovando tal proposta também participaram as Igrejas Evangélicas da Assembléia de Deus, a Igreja Adventista de Sétimo Dia e a Igreja Evangélica Congregacional (Ruedell, 2005).

Omitiu-se o nome deste membro do CONER-RS, a pedido.
} 
denominações religiosas pretendem que a entidade seja uma continuação do grupo interconfessional. Para esse membro, tais denominações religiosas, presentes no CONER-RS, têm grande dificuldade em aceitar a nova modalidade de ensino religioso proposta pela Lei 9475/97. A seu ver, são saudosistas do ensino religioso confessionalcristão nas escolas públicas e tentam de alguma forma minar os objetivos do CONERRS de ampliar o número de denominações religiosas, incluindo grupos não-cristãos e de apoiar um ensino religioso pluralista e não-confessional nas escolas públicas. Segundo esse membro, algumas lideranças religiosas não se dispõem a sentar-se em uma mesma mesa com representantes de religiões afro-brasileiras, espíritas, budistas e outras, pois essas religiões não possuem as mesmas crenças que as denominações cristãs. Para ele, alguns setores ligados à Igreja Católica, no Rio Grande do Sul, estariam se articulando para esvaziar o trabalho do CONER-RS, pois não aceitam um ensino religioso pluralista e uma entidade abrigando denominações não-cristãs.

Historicamente o ensino religioso nas escolas públicas sempre esteve diretamente ligado às denominações religiosas. No Rio Grande do Sul era a Igreja Católica e as Igrejas Luteranas que credenciavam os professores e definiam o conteúdo da disciplina. $\mathrm{O}$ ensino religioso nas escolas públicas tinha um caráter confessional. $\mathrm{O}$ Estado delegava às igrejas a responsabilidade pelo ensino religioso (Ruedell, 2005). O Estado não se imiscui na tarefa de definir um conteúdo específico e capacitar e formar professores para a disciplina, com o fito de manter sua laicidade, sua neutralidade em matéria religiosa. O CONER-RS é o porta-voz, a entidade interlocutora das denominações religiosas junto ao Estado, e deve ser ouvido pelo sistema estadual de ensino no que se refere ao ensino religioso. É o CONER-RS, e não uma denominação religiosa, que auxilia o sistema estadual de ensino na definição dos conteúdos da disciplina de ensino religioso e na formação e capacitação de professores.

\section{AS DENOMINAÇÕES RELIGIOSAS E A OPOSIÇÃO AO ENSINO RELIGIOSO}

Há grande dificuldade, por parte de algumas denominações religiosas, em aceitar o novo modelo de ensino religioso não-confessional e pluralista nas escolas públicas. De acordo com a atual coordenadora do ensino religioso junto à Secretaria da Educação, 
irmã Vilma Rech, algumas denominações querem usar o espaço da escola pública para a doutrinação religiosa e não reconhecem assim o novo modelo de ensino religioso:

Olha, nós temos diversas denominações que ainda não aceitam porque são fundamentalistas. E elas querem fazer doutrinação em sala de aula. Então, elas não aceitam essa nova modalidade porque acham que o ensino religioso tem que ensinar a religião de algumas denominações.

Para a referida coordenadora, algumas igrejas pentecostais e neopentecostais, não concordam com um ensino religioso não-confessional. Alguns desses religiosos enviaram ofícios para a Secretaria da Educação do Estado, pedindo a autorização do secretário da educação para ter acesso às escolas públicas e fazer doutrinação religiosa. Em relação a isso afirma a irmã Vilma Rech:

[...] seguido nós recebemos ofícios de pastores de denominações que não concordam e que gostariam de saber se podem entrar na sala de aula e fazer isso, fazer proselitismo, dar a própria religião. Eles querem espaço para evangelização e fazer uma evangelização proselitista de uma religião só, e não dá.

A pastora metodista Jussara Rotter Cavalheiro, que trabalha na Coordenadoria do Ensino Religioso, declara: "Há resistência ao ensino religioso por parte das igrejas pentecostais, que são, na maioria das vezes, proselitistas e fechadas."

$\mathrm{Na}$ atual configuração do CONER-RS, há apenas um representante de denominação pentecostal, que é a Assembléia de Deus. A Igreja do Evangelho Quadrangular já participou de algumas reuniões do CONER-RS e foi convidada a entrar, mas não decidiu se deve ou não participar. De acordo com a pastora Luila Andersen Bernini, responsável pelo setor de educação religiosa da Igreja do Evangelho Quadrangular, o seu grupo religioso participa de algumas seccionais do CONER-RS no interior do estado. Para a pastora, a escola pública deve ensinar cultura religiosa e não religião. Sobre o objetivo do ensino religioso declara:

[...] não tem como objetivo levar os alunos a se tornarem adeptos de uma ou outra religião, mas sim despertar no educando o cultivo à espiritualidade e uma consciência fundamentada em princípios bíblicos e no cultivo a valores essenciais à dignidade humana, como fraternidade, justiça e paz, que estão presentes no cristianismo e nas demais expressivas religiões da humanidade. 
A pastora da Igreja do Evangelho Quadrangular se opõe a um ensino religioso proselitista, mas ao tratar sobre a necessidade dos valores na formação dos jovens, ressalta a importância dos "princípios bíblicos" e, dessa forma, particulariza o ensino religioso, vinculando-o ao ensino dos princípios éticos presentes na tradição judaicocristã.

Segundo o frei Oscar Andrade Santos, que coordenou o ensino religioso no Rio Grande do Sul, de 1988 a 2002, a Igreja Universal do Reino de Deus ${ }^{6}$ é contra o ensino religioso nas escolas públicas:

Uma denominação religiosa que é radicalmente contra o ensino religioso é a Igreja Universal do Reino de Deus. Eu tive problemas sérios com eles. A Igreja Universal se posiciona literalmente contra o ensino religioso. Eram e são contra porque tinham medo que o ensino religioso servisse aos interesses das igrejas tradicionais e contra as igrejas emergentes. A Igreja Universal temia e teme que os professores de ensino religioso da Igreja Católica fossem fazer em aula um combate contra a Universal do Reino de Deus.

Por sua vez, o pastor José Antônio ${ }^{7}$, da comunidade Sara Nossa Terra, Igreja neopentecostal criada em 1992 pelo bispo Robson Rodovalho, expressa ceticismo em relação ao ensino religioso, enfatizando o predomínio católico no conteúdo da disciplina. Declara o pastor:

Já dei aula de ensino religioso. Pois, como eu sou pastor, a gente conhece a palavra, eu tenho facilidade. Tinha muitos professores despreparados dando aula de ensino religioso na escola onde eu trabalhava. Em vez de falar de cristianismo em si, eles pregavam uma religião. Vi muita coisa errada, por exemplo, o conteúdo programático não é um estudo religioso, é um estudo doutrinário católico, isso é errado. Eu não posso chegar na escola e doutrinar uma criança em determinada religião. A maior parte destes conteúdos programáticos eram feitos por padres e freiras. Em uma escola do estado $90 \%$ do material religioso é católico, coisa que nós evangélicos não concordamos. Se eu sou pastor e meu filho vai estudar numa escola desta, eu não vou querer que ele assista aulas de ensino religioso.

\footnotetext{
Não foi possível entrevistar representantes da Igreja Universal do Reino de Deus e da Igreja Deus é Amor. Foram feitos inúmeros contatos, mas seus pastores negaram-se a conceder entrevistas.

O pastor José Antônio é professor de Educação Física na Escola Pública Itororó, de Guaíba, e ministrou aulas de ensino religioso nessa mesma escola.
} 
Para o pastor Daniel Corrêa dos Santos, que preside a Federação das Associações de Igrejas Evangélicas do Rio Grande do $\mathrm{Sul}^{8}$, e é membro da Igreja Pentecostal Eslava, o ensino religioso deve basear-se no Cristianismo. Na medida em que:

O ensino religioso deve estar vinculado com o estudo da Bíblia sagrada, observando a palavra de Deus. Deve transmitir uma noção de moral, de que há um ser superior. Uma linha cristã, sem lavagem cerebral, sem induzir as pessoas. Estudando Deus, o que é Deus, sua glória, seu poder, suas manifestações, etc.

Outro ponto de vista apresentado é o da psicopedagoga Evandra Soares de Vargas, ligada a Igreja Cristã Manancial de Vida, em suas palavras temos que: "O ensino religioso deveria se basear no criacionismo. Meu embasamento teórico seria a Bíblia, mas devemos nos adequar ao lugar que estamos trabalhando. Eu utilizaria a Bíblia como único recurso teórico.”

Grande parte dos representantes das igrejas pentecostais e neopentecostais entendem que a família e os templos são os locais mais apropriados para o ensino da religião e não a escola pública. Não simpatizam com um ensino religioso pluralista e macro-ecumênico, aberto a outras tradições religiosas não-cristãs. Para esses grupos religiosos, o ensino religioso deve estar fundamentado no Cristianismo, tendo como livro base a Bíblia.

No próprio CONER-RS há denominações religiosas que se mostram resistentes em aceitar um ensino religioso pluralista nas escolas públicas. São denominações que, apesar de nominalmente fazerem parte da atual estrutura do CONER-RS, não têm participado das reuniões da entidade. Os Adventistas ${ }^{9}$ fazem parte do CONER-RS, mas não têm mostrado muito interesse e entusiasmo por este novo ensino religioso. Os Israelitas também não têm participado dos eventos e encontros do CONER-RS.

Os espíritas kardecistas não participam do CONER-RS e declaram-se contra o ensino religioso nas escolas públicas. A vice-presidente da Federação Espírita do Rio Grande do Sul, maior entidade espírita do estado, Gládis Pedersen de Oliveira, diz que nunca foram convidados a participar do CONER-RS e nem foram informados oficialmente sobre a existência dessa entidade. A seu ver: "A instituição família é que deve orientar a questão religiosa. Essa não deve ser uma competência da escola

\footnotetext{
8 A federação foi criada em dezembro de 2003 e congrega cerca de 50 organizações religiosas.

Só no final de 2005 voltaram a comparecer em algumas reuniões do CONER-RS. Ficaram durante sete anos sem participar das reuniões e encontros do CONER-RS.
} 
pública." Para a Federação Espírita do Rio Grande do Sul, a religião é assunto privado, não devendo ser ensinada nas escolas públicas.

As lideranças dos cultos afro-brasileiras concebem o novo ensino religioso plural e não proselitista nas escolas públicas do estado do Rio Grande do Sul como uma oportunidade para que sua religião também seja ensinada nas escolas. No entanto, não há qualquer representante de entidades afro-brasileiras participando ativamente na implementação desse novo modelo de ensino religioso.

O CONER-RS alega que o problema com os afros está em sua atomização e na falta de uma organização representativa. Por outro lado, alguns grupos religiosos afrobrasileiros no estado suspeitam que o ensino religioso nas escolas públicas seja utilizado para satisfazer o interesse de grupos religiosos hegemônicos. Para o babalorixá Baba Diba de Yemanjá, importante liderança religiosa afro no estado, a escola pública não é o local mais apropriado para o ensino da religião. Afirma Baba Diba: "Para nossa tradição, a religião de matriz africana não tem que ser ensinada nas escolas. Tradição de matriz africana tem que ser apreendida dentro do terreiro." Segundo o Babalorixá Baba Diba:

O Estado é laico, se a escola começar a ensinar uma determinada religião ela vai estar onerando o Estado, favorecendo uma determinada religião, o que acontece até hoje em relação a Igreja Católica. Se o Estado é laico ele não tem que favorecer uma religião.

Há também alguns setores na Igreja Católica que não aceitam essa nova modalidade de ensino religioso nas escolas públicas. Esses grupos e lideranças defendem um ensino religioso confessional cristão. De acordo com Carmem Roweder ${ }^{\mathbf{1 0}}$, que trabalha no setor de ensino religioso da CNBB, de Porto Alegre, "há uma resistência em relação a esse novo ensino religioso por parte de alguns bispos, não é algo explícito esta resistência."

A ex-diretora do FONAPER (Fórum Nacional Permanente do Ensino Religioso), Lurdes Caron ${ }^{\mathbf{1 1}}$, que é a principal entidade nacional responsável pelo ensino religioso, afirma que "a ala conservadora da Igreja Católica está silenciosa na questão do ensino religioso." E acrescenta: "de forma velada os bispos querem que o ensino

\footnotetext{
10 Carmem Roweder trabalhou durante anos como professora de ensino religioso em escolas públicas no interior do estado do Rio Grande do Sul, quando este ensino era ainda confessional.

Lurdes Caron pesquisa o ensino religioso nas escolas públicas. Defendeu dissertação de mestrado na EST (Escola Superior de Teologia), de São Leopoldo, sobre o ensino religioso nas escolas públicas de Santa Catarina e trabalhou na CNBB como assessora para questões sobre o ensino religioso.
} 
religioso esteja a serviço da evangelização, mas os bispos estão divididos." Para Lurdes Caron, "a tendência é que volte o ensino religioso confessional. Isso já está acontecendo no Rio de Janeiro e na Bahia."

De acordo com a pastora metodista Jussara Cavalheiro, o fato de grande parte das reuniões e encontros promovidos pela Coordenadoria se realizarem na Livraria Paulinas já revela certo confessionalismo. Assevera Jussara:

\begin{abstract}
Quando nós fazemos um encontro na Livraria Paulinas nós estamos sendo confessionais porque enquanto o encontro não começa, eles estão passando slides do material que possuem. Quando tu entras nesta livraria tu tens os livros, todo o ambiente é católico [...]. Nós temos o discurso, mas há dificuldades. Quando um pastor luterano ou da Assembléia de Deus faz uma palestra em alguma seccional no interior do estado e termina sua exposição com um hino cristão, evangélico, nós vemos uma resistência por parte da Coordenação do Ensino Religioso [...]. Quando é outra denominação não católica se pontua muito.
\end{abstract}

Importante ressaltar que esse depoimento é de alguém que trabalha na Coordenadoria do Ensino Religioso da Secretaria de Educação e que destaca a hegemonia católica na organização do ensino religioso no Rio Grande do Sul. A pastora metodista revela que os membros católicos da coordenadoria "vigiam" com zelo o discurso de líderes religiosos de outras denominações, quando se realiza algum encontro promovido pela coordenadoria.

\title{
A AUSÊNCIA DO ENSINO RELIGIOSO DAS ESCOLAS PÚBLICAS MUNICIPAIS DE PORTO ALEGRE
}

As escolas públicas municipais de Porto Alegre não oferecem a disciplina de ensino religioso; seu conteúdo é abordado de forma transversal na disciplina de Filosofia. A referida disciplina não era oferecida pelas escolas públicas municipais, quando a prefeitura de Porto Alegre era administrada pelo Partido dos Trabalhadores, que decidiu não incluir o ensino religioso nas escolas públicas em nome da laicidade da educação. Foi uma decisão política que visava manter a escola pública distante de qualquer forma de instrução religiosa.

Para o presidente do CONER-RS, padre Enrique Ilarze, isso se deve a um "ranço marxista" presente na Secretaria de Educação do município, comandada pelo partido 
dos trabalhadores, que via com maus olhos o ensino religioso nas escolas públicas. A seu ver, havia na época um "núcleo anticlerical” na Secretaria de Educação. Para Neusa Herbert, que foi coordenadora da educação religiosa de 1993 a 1997 na Secretaria Municipal de Educação de Porto Alegre, a questão não pode ser vista dessa forma.

Nós fizemos uma discussão em 1996 e 1997 de manter o ensino religioso como estava ou mudar com outro nome, chegou-se a cogitar a terminologia de Cultura Religiosa. Havia um grupo que defendia Cultura Religiosa e outro grupo que defendia Filosofia da Religião. Não foi uma discussão só em torno do nome.

Para a então coordenadora do ensino religioso na administração petista, o que estava em jogo era manter o ensino religioso em sua forma confessional cristã ou abrirse a uma perspectiva pluralista e inter-religiosa. A proposta de suprimir o nome ensino religioso e a "antiga" forma confessional de ensino dessa disciplina e adotar um modelo supraconfessional foi vitoriosa. De acordo com Neusa Herbert, o modelo por ela defendido muito se assemelhava com o atual modelo de ensino religioso. A modificação do nome de ensino religioso para Filosofia visava superar o modelo confessional cristão desse ensino, afirma a ex-coordenadora:

No regimento da escola por ciclos está dito que ela é laica e pluralista. $\mathrm{O}$ regimento foi feito por nós. $\mathrm{O}$ regimento não chega a dizer que estamos transitando da cultura religiosa para a Filosofia. Ele afirma que a Escola Pública é Laica e Pluralista. E ele coloca, esboça no seu conjunto de disciplinas a Filosofia. O projeto estava esboçado em 1997. O grupo optou por Filosofia da Religião e posteriormente, ficou Filosofia.

Para a coordenadora do ensino religioso na administração municipal petista, o ensino religioso ficou contemplado na Filosofia. Com o objetivo de manter a laicidade da escola pública, a administração petista suprimiu a disciplina de ensino religioso. Entretanto é mister destacar que alguns setores mais à esquerda do Partido dos Trabalhadores no estado são abertamente laicistas e contrários a qualquer tipo de instrução religiosa nas escolas públicas. O coordenador do setor de educação do Partido dos Trabalhadores no Rio Grande do Sul, Cláudio Sommacal, manifesta sua oposição ao ensino religioso:

[...] enquanto petista, entendo que o Ensino Religioso não deva constar como matéria específica no currículo escolar das escolas de 
Ensino fundamental e Médio. Muito menos nas instituições de ensino superior confessionais. Esta é uma deformação histórica que haveremos de superar com tempo. Todos sabemos que o Ocidente é fortemente influenciado pelo Cristianismo e seus resquícios se manifestam, por exemplo, na obrigatoriedade do Ensino Religioso, excessivamente confessional católico, e cheio de dogmas. Entendo que o fenômeno religioso deva ser parte integrante de disciplinas que tratam da transversalidade como a Filosofia, a Sociologia ou a História.

\section{REGULAMENTO PARA OS DOCENTES DE ENSINO RELIGIOSO NAS ESCOLAS PÚBLICAS}

A Lei Federal 9.475/97 estabelece, em seu parágrafo $1^{\circ}$, que os sistemas estaduais de ensino regulamentarão os procedimentos para a definição dos conteúdos do ensino religioso e estabelecerão as normas para a habilitação dos professores. Anteriormente o professor de ensino religioso nas escolas públicas era credenciado, autorizado a dar aulas pela denominação religiosa competente. Com a nova modalidade de ensino religioso, a responsabilidade pela capacitação, habilitação e admissão dos professores de ensino religioso nas escolas públicas recai sobre o sistema de ensino. Assim, cabe às escolas públicas a definição do conteúdo da disciplina e a contratação e a formação de professores. Neste sentido, a norma jurídica objetiva desvincular o ensino religioso das confissões religiosas.

No estado do Rio Grande do Sul, o Conselho Estadual de Educação vem emitindo pareceres que visam regulamentar a capacitação e formação de professores. $O$ referido Conselho emitiu, em 22 de março de 2000, a Resolução $n^{\circ}$. 256, que regulamenta a habilitação de professores de ensino religioso e os procedimentos para a definição dos conteúdos desse componente curricular. Diz o artigo $1^{\circ}$ dessa Resolução:

São habilitados a lecionar Ensino Religioso em escolas integrantes do Sistema Estadual de Ensino os professores: I - titulados em nível médio ou superior para a docência na educação infantil e/ou nos quatro anos iniciais do ensino fundamental, para atuar nesses níveis da escolarização; II - os licenciados em qualquer área do currículo que tenham realizado curso ou cursos de preparação para lecionar o componente curricular Ensino Religioso, para atuar nos quatro anos finais do ensino fundamental e no ensino médio.

O Conselho Estadual de Educação do estado do Rio Grande do Sul define que o professor de ensino religioso, a partir da $5^{\mathrm{a}}$ série, deve ser licenciado em alguma área do 
conhecimento e cumprir um curso especial de ensino religioso de 400 horas letivas. A situação gaúcha difere de São Paulo que, através da Lei estadual 10.783 de 2001, determina que apenas os indivíduos formados em Ciências Sociais, Filosofia e História podem ministrar aulas de ensino religioso. No estado de São Paulo, o ensino religioso é ensinado como História das Religiões e o material e o conteúdo para a capacitação de professores foi elaborado por uma equipe de professores doutores de História da UNICAMP (Dickie e Lui, 2005).

Não há ainda no estado do Rio Grande do Sul um curso de licenciatura em ensino religioso. Dessa forma, os professores que ministram a disciplina são das mais diversas áreas. Com o objetivo de seguir essa orientação diversas instituições de ensino superior oferecem cursos de extensão e especialização, para formar professores de ensino religioso para as escolas públicas.

Em abril de 2005, ocorreu o primeiro concurso público para professores de ensino religioso no estado. O objetivo da Coordenadoria do Ensino Religioso na Secretaria de Educação era criar o cargo de professor de ensino religioso por meio de concurso ou nomeação visando valorizar o profissional dessa área, hoje desprestigiado.

O INTERESSE DOS ALUNOS PELA DISCIPLINA DE ENSINO RELIGIOSO E OS CONTEÚDOS CURRICULARES

No imaginário dos alunos e de grande parte da população, a disciplina de ensino religioso é uma forma de catequese, de doutrinação religiosa. De acordo com a professora de ensino religioso, Maria Júlia Cunha Saraiva: "Os alunos não têm interesse. Temos que estar fazendo coisas diferentes. Agora estamos trabalhando sobre trânsito, mas há muita bagunça nas aulas, piadinhas; ensino religioso, eles não têm interesse." Esse desinteresse está vinculado à imagem que os alunos têm da disciplina como algo ligado à religião. Afirma a Professora Maida, que dá aulas de ensino religioso no Colégio Rio Branco, em Porto Alegre: "Os alunos têm preconceito em relação ao ensino religioso, ao nome 'ensino religioso'. Pensam que é ensino de uma religião, catequese, e que uma irmã vai dar aula."

Embora a proposta atual de ensino religioso não tenha mais o caráter confessional e catequético que teve ao longo da história brasileira, essa visão predomina no imaginário dos alunos, que logo associam o ensino religioso nas escolas públicas com o ensino de uma religião, com catequese e doutrinação religiosa. A professora 
Jussara Rotter Cavalheiro, que já ministrou aulas de ensino religioso em escolas públicas, destaca a resistência ao ensino religioso por parte das famílias e direções de escolas:

Nas escolas públicas, há restrições, resistências, por parte das famílias e por parte da direção das escolas. As famílias ainda estão com aquela idéia do ensino religioso confessional. As direções das escolas ainda têm muita resistência a esta disciplina, pois imaginam que o ensino religioso seja direcionado, confessional e acreditam que esta disciplina seja irrelevante.

É importante destacar que o ensino religioso é considerado atualmente uma área de conhecimento como a matemática, o português, etc. A resolução $\mathrm{n}^{\circ} .2$ do Conselho Nacional de Educação, de 7 de abril de 1998, estabelece que o ensino religioso, a educação religiosa é uma das dez áreas de conhecimento ${ }^{12}$, uma disciplina própria com objeto de estudo e conteúdo próprio, que deve estar presente no sistema de ensino.

A Resolução $n^{\circ}$. 256, de 22 de março de 2000, de autoria do CEE (Conselho Estadual de Educação) do Rio do Grande do Sul, regulamenta a habilitação de professores de ensino religioso e os procedimentos para a definição dos conteúdos desse componente curricular. $\mathrm{O}$ artigo $3^{\circ}$ dessa resolução estabelece:

Os conteúdos do componente curricular Ensino Religioso são fixados pela escola, de acordo com seu projeto pedagógico, observadas as diretrizes curriculares nacionais e com base em parâmetros curriculares que serão estabelecidos sob a coordenação da Secretaria de Educação.

Em outubro de 2005, a Coordenação do Ensino Religioso na Secretaria de Educação do Estado trouxe a tona um modelo de referencial curricular para o ensino religioso da educação básica do sistema estadual de ensino. Este documento foi publicado oficialmente em 2006, como parâmetro curricular estadual para o ensino religioso. Participaram na elaboração e estruturação, além da Coordenadoria do Ensino Religioso na Secretaria de Educação, os Coordenadores de Ensino Religioso da Divisão Porto Alegre e o CONER-RS. Na análise do documento fizeram parte o CONER-RS e o GREFERE (Grupo de Estudos para a Formação para o Ensino Religioso Escolar), ligado à Igreja Católica.

12 As áreas de conhecimento definidas por essa resolução são: Língua Portuguesa, Língua Materna (para população indígena e migrante), Matemática, Ciências, Geografia, História, Língua Estrangeira, Educação Artística e Educação Física. 
O referencial curricular estadual foi elaborado pela base, isto é, por professores que ministram o ensino religioso nas escolas públicas, a partir de sua experiência e prática. Esse referencial procura seguir os Parâmetros Curriculares Nacionais do ensino religioso e tem um caráter sugestivo. A Coordenação do Ensino Religioso quer dar uma direção para o conteúdo do ensino religioso, visando evitar o proselitismo e a doutrinação religiosa. Na introdução do referencial curricular estadual, é afirmado:

Definir um currículo não é tarefa fácil; mais difícil se torna quando o currículo a ser construído deve resgatar o diálogo, o respeito e a reverência pela diversidade cultural e religiosa que se impõe em um Estado de diferentes composições étnicas. A valorização da diversidade de manifestações do fenômeno religioso e as formas encontradas pelo ser humano para entender, vivenciar e rememorar essas manifestações são a temática central do Ensino Religioso em seu paradigma atual.

De acordo com as orientações da Secretaria de Educação do Rio Grande do Sul:

Os conteúdos devem ser fixados pela Escola, partindo-se dos Parâmetros Curriculares Nacionais do Ensino Religioso - PCNER, definidos pelo Fórum Nacional Permanente do Ensino Religioso FONAPER - considerando o proposto no Projeto Pedagógico, observadas as Diretrizes Curriculares Nacionais e os parâmetros curriculares a serem fixados pela SE/RS, ouvindo o CONER/RS (Res. CEED/RS 256/2000). ${ }^{13}$

Observa-se com isso, a preocupação dos agentes sociais, envolvidos na elaboração do referencial curricular estadual, em adotar um discurso que respeite a diversidade cultural e religiosa e na construção de um parâmetro curricular fundamentado no dialogo inter-religioso e que tenha como objeto o fenômeno religioso e não uma religião em particular.

\section{CONSIDERAÇÕES FINAIS}

O novo modelo de ensino religioso nas escolas públicas brasileiras advindo da Lei federal 9/475/97, busca se adaptar à atual situação pluralista do campo religioso brasileiro.

O ensino religioso já não é mais, ao menos juridicamente e formalmente, monopólio de um grupo religioso. Desta maneira, o novo ensino religioso assume, em

13 Citação retirada do folheto "O Ensino Religioso no Sistema Estadual de Ensino do Rio Grande do Sul” - Orientações Técnicas para a Oferta do Ensino Religioso - elaborado pela Secretaria de Educação do Estado do Rio Grande do Sul, no ano de 2004. 
sua formulação jurídica, nos parâmetros curriculares nacionais e na fala dos sujeitos sociais responsáveis pela implantação dessa disciplina nas escolas gaúchas, um caráter não-confessional, pluralista e contrário a qualquer forma de doutrinação e proselitismo religioso.

Contudo, durante a pesquisa de campo constatou-se um contraste entre o ideal preconizado pela lei federal, os parâmetros curriculares nacionais, a fala dos membros do CONER-RS e da Coordenaria do ensino religioso na Secretaria de Educação e a realidade concreta. Nas salas de aulas, é ainda muito freqüente o ensino religioso com fins proselitistas e de catequização, distante do preconizado ensino religioso supraconfessional e centrado na análise do fenômeno religioso.

Observou-se ainda a resistência de algumas organizações religiosas a este novo modelo e a formação de uma organização interconfessional - CONER/RS - responsável pela definição de conteúdos programáticos para esta disciplina. O CONER/RS e a coordenação do ensino religioso na Secretaria Estadual de Educação são os dois principais atores envolvidos na implantação desta disciplina em sua nova modalidade.

É importante aqui destacar a guisa de conclusão que as relações entre a escola e o religioso são dependentes das relações entre o Estado e as Igrejas, entre o poder político e as organizações religiosas existentes em uma sociedade (Willaime,2003). A forma como esse ensino se apresenta nas escolas públicas vincula-se com a história religiosa de cada país e com a configuração do campo religioso de determinada sociedade (Pajer, 2005).

\section{REFERÊNCIAS}

BRANDENBURG, Laude, Erandi FUCHS, Henri Luiz; KLEIN Remi; WACHS, MANFREDO Carlos. (Orgs). Ensino religioso na escola: bases, experiências e desafios. São Leopoldo: Oikos, 2005.

CNBB. O ensino religioso. São Paulo: Paulinas, 1987.

CONER. Plano de Estudos: ensino religioso. São Leopoldo, 2003.

DICKIE, Maria Amélia Scmidt; LUI, Janayna Alencar. O ensino religioso e a interpretação da lei. Horizontes Antropológicos, Porto Alegre, v.13, n. 27, p.237-252, 2007. 
FIGUEIREDO, Anísia de Paulo. O ensino religioso no Brasil: tendências, conquistas e perspectivas. Petrópolis: Vozes, 1996.

FILHO, Sylvio Fausto Gil. O ensino religioso nas escolas públicas do Brasil: discurso e poder frente ao pluralismo religioso. Revista Diálogo Educacional, Curitiba, v. 5, n. 16, p.121-145, set./dez. 2005.

GIUMBELLI, Emerson. Religião, estado e modernidade: notas a propósito de fatos provisórios. Estudos Avançados, São Paulo, v.18, n. 52, p.47-62, dec. 2004.

GIUMBELLI, Emerson; CARNEIRO, Sandra de Sá. Ensino religioso no estado do Rio de Janeiro: registros e controvérsias. Comunicações do Iser, Rio de Janeiro, ano 23, n.60, p.7-154, 2004.

MARIANO, Ricardo. Efeitos da secularização do Estado, do pluralismo e do mercado religioso sobre as igrejas pentecostais. Civitas, Porto Alegre, v.3, n.1, p.111-125, jun.2003.

PAJER, Flavio. Scuola e istruzione religiosa nell' Europa multireligiosa: problemi e sfide. Disponível em: www.cestim.it. Acesso em: 26 jan. 2007.

RUEDELL, Pedro. Trajetória do ensino religioso no Brasil e no Rio Grande do Sul. Porto Alegre: Sulina, 2005.

.Ensino religioso e ensino superior. Porto Alegre. 2002.

TEIXEIRA, Ricardo A. G. O Ensino Religioso nas Escolas Públicas Municipais de Aparecida de Goiânia. Dissertação (Mestrado em Ciências da Religião)-PPGCR/UCG, Goiânia, 2002.

WILLAIME, Jean-Paul. L' enseigne des faits religieux: perspectives européenes. Disponível em: http://eduscol.educstion.fr/D0126/fait_religieux_willaime.htm. Acesso em: 20 out. 2006. 